\title{
Forecasting and Measuring The Impact on Non-Tax Revenue of Its Principal Determinants in Nepal
}

\author{
Arjun Kumar Dahal \\ Mechi Multiple Campus, Bhadrapur, Jhapa, Nepal \\ Email: 1arjundahal@gmail.com/ arjun.dahal@ memc.tu.edu.np \\ ORCID id: https://orcid.org/0000-0003-4816-4576
}

\begin{abstract}
This study aims to examine the impact on non-tax revenue of its principal determinants like charges, fines, fees, forfeiture, dividend, principal and interest payment, income received from sales, Royalty, and sales from fixed assets. It also explores the ex-post forecasting of non-tax revenue. It is based on the secondary data taken from various economic surveys of Nepal covering from 1980 to 2019. Descriptive and exploratory research designs are used to examine the impact and forecast the dependent variable. Some statistical and econometric tools like descriptive statistics, unit root testing, ordinary least square, serial correlation, heteroscedasticity test, and dynamic ex-post forecasting approaches. There is a positive impact on non-tax revenue of its principal determinants. The income received from principal and interest payment is found more consistent, whereas the non-tax revenue from sales government goods and services is found more inconsistent than other variables. The value of root means squared error is encountered very small (i.e., 0.7865). So, the gap between actual and forecasted nom-tax revenue is tiny. The results, design, and techniques of this study are not affected by the results and findings of other researchers.
\end{abstract}

Keywords: Consistent, forfeiture, root mean squared error, ex-post, dynamic forecasting.

JEL Selection: P43, C32, C53.

\section{How to Cite:}

Dahal, A. K. (2021). Forecasting and measuring the impact on non-tax revenue of its principal determinants in Nepal. Journal of Accounting and Taxation, 1(1). 43 - 54. DOI. https://doi.org/10.47747/jat.v1i1.463

\section{Introduction}

The government of a country collects required funds through various taxes, non-taxes, and public borrowing. The government requires a considerable amount of resources for carrying out further development and welfare activities in the country, which it collects imposing taxes and non-taxes. (Ghimire, 2019). Among the other sources of public revenue, the non-tax revenue is essential and comparatively less burden-bearing to the general public. The origins of 
non-tax revenue are divided into six parts in Nepal. Like (a) charges, fees, fines, and forfeiture,(b) receipts from sale goods and services,(c) dividend, (d) Royalty and sale of fixed assets, (e) principal and interest payment, and (f) Miscellaneous items.

Firm registration charges, arms registration charges, vehicle license, judiciary fines, penalty, forfeiture, and administrative tasks fall under charges, fees, fines, and forfeiture. Bill of drinking water, irrigation, education, postal service, food and agriculture, electricity, forest, and transport falls under receipts from sales of goods and services. Dividend comprises financial institutions trading concerns, industrial undertakings, service sector, and other related factors. Similarly, Royalty from mining, mountains, and tourist sites falls under the heading of Royalty and sales of fixed assets. Principal and interest payment comprises loans to corporations and interest from loans to companies and corporations (GoN, 2020). Non-tax revenue is a significant source of generating revenue capacity of the government. Dividend, charges, and income received from Royalty and sales from government goods and services ordinarily adequate to determine non-tax revenue (Kulshrestha and Sharma, 2015)

While taxation is a primary source of government income, it also earns some recurring income other than tax, known as non-tax revenue. The payment obtained by the government from other sources other than tax is called non-tax revenue. Fees, fines or penalties, betterment levy or special assessment, grants and gifts, deficit financing, license fees, natural resources. The profit of public enterprises and escheats are excellent sources of revenue other than tax (Dahal, Dhakal, et al., 2020). Tax revenue is the most significant source of revenue for the government. Still, the amount of tax collection may vary due to the employment situation, consumption level, etc. The non-tax revenue is somewhat balanced with a low but steady flow of revenue from many sources. Apart from earning for the government, non-tax revenues help recover the cost of services offered (Gupta, 2007). The non-tax revenue from financial services comprises receipts from crops industry, animal husbandry, fisheries, forestry and wild lives, corporations, other agricultural and rural programs, major and minor irrigation, village and small scale industries, plantations, power, petroleum, lighthouses, road transport tourism and others (Mohanty and Patra,2016). Non-tax revenue has certain advantages as compared to taxes. They do not have disincentive potentials, which generally go up the high tax rate (Poterba, 2011). Non-tax revenue does not create various economic problems. Most of the non-tax revenue sources contain an element of quid-pro-quo and price (Niyazmetor, 2018).

This study explores the impact on non-tax revenue of its principal determinants. It also shows the actual condition of non-tax revenue and its main determinants over 40 years from 1980 to 2019. Finally, it also aims to the ex-post forecast of non-tax revenue during eight years whether it is near actual data or not.

\section{Literature Review}

Many types of research are related to tax revenue and its impacts on the size of budget or government expenditure or investment or GDP. The various study can be found on the effects of tax revenue on its main determinants. Still, microscopic research is related to the influence and impact on non-tax revenue and its principal determinants. Therefore, some relevant studies on non-tax income in public finance are reviewed. 
Upender (2008), Kaur and Gursimran (2010), Bagchi (2005), Kaur (1991), Mawia and Nzomoi (2013), Mohantly (2014) pointed out that non-tax revenue has accounted for a small and declining share of total revenue in their respective country.

The world development bank (2012) examined the trends of non-tax revenue in Nepal. It observed that the determinants are individually significant to explain the non-tax revenue.

Mourre and Reut (2017) examined the characteristics of government non-tax revenue in the European Union. It is found that the receipts from sources other than Taxes amount to slightly more than one-tenth of the total income. Still, the fiscal risk steaming from the volatility of non-tax revenue is three times higher than that from tax revenue volatility. Panel data analysis examines whether macroeconomic and budgetary variables can explain the differences in nontax revenue among the member countries. The more significant part of non-tax revenue consists of intakes from sales of goods and services. Reliance on non-tax revenue is higher for local government compared to the central government.

Purohit, and purohit (2009). Observed the contribution of various sources of non-tax revenue and its mobilization. They found the long-run and positive associations between non-tax revenue and its determinants like charges, dividend, betterment levy, and others. Prichard, Salard, et al. (2018) observed strong evidence of the positive impact of non-tax revenue to determine the size of budget and democracy. It was based on the norms that less dissatisfaction with the public's tax guarantees the democratic government.

\section{Research Method}

\subsection{Research design}

This study is based on descriptive and exploratory research design, and the outcomes are analyzed. It is based on the 40-time series annual points. The dynamic forecasting model is used to explore the impact, and ex-post forecasting is used to check the predicting power of the model.

\subsection{Variable specification}

The charges, fines fees, forfeiture, dividends, principal and interest payment, revenue received from sales, Royalty, and sales from fixed assets are taken as independent variables. In contrast, non-tax revenue is taken as the dependent variable. Therefore, this study solely depends upon secondary data collected from various economic surveys. To analyze and derive the required conclusion from the collected secondary data.

\subsection{Model specification}

Depending upon the assumptions of two inputs labour and capital are used in the production process, the Cobb-Douglas production is;

$$
Y_{t}=A K^{\alpha} L^{\beta}
$$

Where, $\mathrm{Y}_{\mathrm{t}}=$ Real output $\quad \mathrm{K}=$ Capital $\quad \mathrm{L}=$ Labour

$\mathrm{A}=$ Efficiency Parameter 
$\bar{\alpha}$, and $\beta$ shows the contribution of capital and labour in the production process, respectively. It is assumed that $\alpha$ and $\beta$ have a positive contribution to the production process. The sum of $\alpha$ and $\beta$ is always 1 .

The non-tax revenue depends on charges, fees, fines, forfeiture, dividends, principal and interest payment, and Royalty. In this sense,

$\mathrm{NTR}=\mathrm{f}(\mathrm{CFF}, \mathrm{DD}, \mathrm{PI}, \mathrm{RFS}, \mathrm{RS})$

Where NTR stands for the amount of non-tax revenue, CFFF stands for charges, fees, fines, and forfeiture, D.D. means dividend, P.I. means principal and interest payment, RFS stands for revenue received sales. R.S. means Royalty and income received from fixed assets. The static regression model:

$\mathrm{LnNTR}=\beta_{0}+\beta_{1} \mathrm{LnCFFF}+\beta_{2} \mathrm{LnDD}+\beta_{3} \mathrm{LnPI}+\beta_{4} \mathrm{LnRFS}+\beta_{5} \mathrm{LnRS}+\mu_{\mathrm{t}}$

In equation (3), $\beta_{0}$ indicates the intercept of the regression line. $\beta_{1} \beta_{2} \ldots . . \beta_{5}$ shows the coefficient of respective variables as shown in equation (3). $\mu_{t}$ is the error correction term of the equation. In dynamic model the lagged values of dependent variable has entered as repressors (Gujarati, 1995). The dynamic regression model is specified as:

$\operatorname{LnNTR}=\beta_{0}+\beta_{1} \operatorname{LnNTR}(-1)+\beta_{2} \operatorname{LnCFFF}+\beta_{3} \operatorname{LnDD}+\beta_{4} \operatorname{LnPI}+\beta_{5} \operatorname{LnRFS}+\beta_{6} \operatorname{LnRS}+\mu_{\mathrm{t}}$

Where, LnNTR(-1) stands for autoregressive variable of LnNTR. It is lag 1 variable of non-tax revenue which is treated as independent variable.

\section{Finding and Discussion}

\subsection{Condition of non-tax revenue and its determinants}

The condition of non-tax revenue and its principal determinants like charges, fees, fines, and forfeiture, dividends, principal and interest payment, receipts from the sale, Royalty, and sales from fixed assets are considered. All variables are gradually increasing, but slight variation occurs. The condition of non-tax revenue and its principal determinants from 1980 (the fiscal year 1978/80) to 2018 is presented in figure 1. 


\section{Condition of Non-tax revenue and its principal determinants}

200000

150000

100000

50000

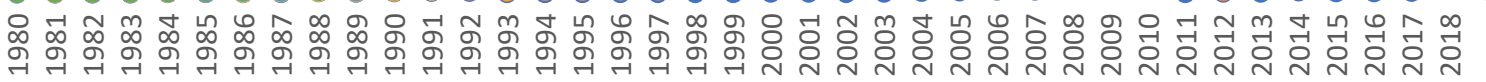

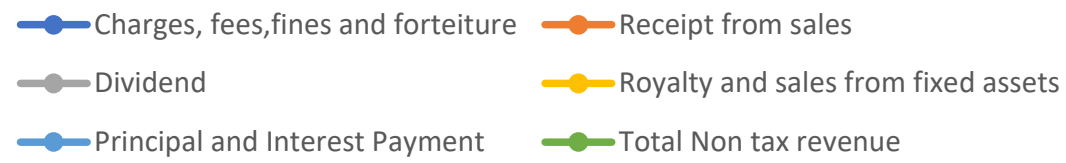

Figure 1: Condition of non-tax revenue and its determinants

Source of data: Economic Survey of Nepal 2000/01 (GoN, 2001), 2008/09 (GoN, 2009).

2019/20 (GoN, 2020).

Descriptive Statistics

Table 1

Descriptive statistics of variables

Source: Authors Calculation

\begin{tabular}{|lcccccc|}
\hline & NTR & DD & CFFF & PI & RFS & RS \\
\hline Mean & 17090.00 & 4886.932 & 982.9438 & 2269.388 & 4647.287 & 2389.441 \\
\hline Median & 9120.000 & 2059.650 & 420.5000 & 2084.400 & 1973.100 & 564.2500 \\
\hline Maximum & 85582.00 & 24741.70 & 6180.400 & 17180.30 & 25674.20 & 12079.10 \\
\hline Minimum & 351.2000 & 80.00000 & 29.70000 & 29.10000 & 145.0000 & 16.10000 \\
\hline Std. Dev. & 2186.42 & 6465.218 & 1290.045 & 2773.868 & 6990.191 & 3386.065 \\
\hline Skewness & 1.613749 & 1.488664 & 2.550535 & 3.934743 & 2.071360 & 1.333705 \\
\hline Kurtosis & 4.831034 & 4.235819 & 9.663689 & 22.08579 & 6.150940 & 3.506889 \\
\hline Jarque-Bera & 22.94904 & 17.31955 & 117.3761 & 710.3268 & 45.15091 & 12.28669 \\
\hline Probability & 0.000010 & 0.000173 & 0.000000 & 0.000000 & 0.000000 & 0.002148 \\
\hline Coeff. Of vari. & 123.97 & 132.30 & 131.24 & 122.22 & 150.41 & 141.71 \\
\hline Sum & 683600.2 & 195477.3 & 39317.75 & 90775.52 & 185891.5 & 95577.64 \\
\hline Sum Sq. Dev. & $1.75 \mathrm{E}+10$ & $1.63 \mathrm{E}+09$ & 64904450 & $3.00 \mathrm{E}+08$ & $1.91 \mathrm{E}+09$ & $4.47 \mathrm{E}+08$ \\
\hline Observations & 40 & 40 & 40 & 40 & 40 & 40 \\
\hline
\end{tabular}

NTR= Non-tax revenue

$\mathrm{DD}=$ Dividend

$\mathrm{CFFF}=$ Charges, fines, fees, and forfeiture R.S. $=$ Royalty and sales from fixed assets.

Publihsed by:

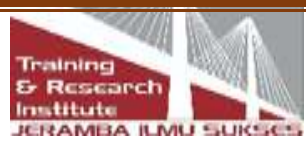


The mean value of non-tax revenue is found 17090 million rupees during 40 years from 1980 to2018. The non-tax revenue ranges from 351.2 to 85582.0 million rupees. The second highest mean is received from dividends, 4886.932 million rupees during 40 years, followed by payment received from fixed-assets sales. The distribution of all variables is positively skewed, and the data related to income received from Royalty and sales from fixed assets is approximately Mesokurtic. The standard deviation of income received from charges, fines, fees, and forfeiture is less than others so, the average revenue received from these sources is more representative. The coefficient of variation of principal and interest payment is small $(122.22 \%)$ than other variables. So the income received from principal and interest payment is more stable or consistent.

Similarly, the coefficient of variation of income obtained from sales is the highest. So, income received from this source is more variable or inconsistent than other non-tax revenue sources. The descriptive statistics of variables are presented in Table 1.

\subsection{Measurement of relation among variables}

Ordinary least squares observe the measurement of relation and impact between variables. To run the regression model, lag selection and unit root testing are performed here.

\section{Lag selection}

Lag selection is how many terms back down the autoregressive process. It helps to identify the affecting period of one variable by itself. Akaike Information criteria (AIC), Final Predictor Error (FPE), Schwarz Information criteria (SIC), Hanna-Quinn Information Criteria (HQI), Sequential modified L.R. test statistics (L.R.) are the principal methods for lag selection. AIC and SIC values indicate one as optimum lag. All criteria suggest selecting lag one, which is showing by asterisks (*). The minimum value of AIC and SIC indicates lag one, which is regarded as the best method of lag selection. The outcomes of all criteria of lag selection are presented in Table 2.

\section{Table 2}

Outcomes of different lag selection criteria.

\begin{tabular}{|c|c|c|c|c|c|}
\hline \multicolumn{6}{|c|}{ Endogenous variables: LnNTR LnDD LnCFFF LnPI LnRFS LnRS } \\
\hline \multicolumn{6}{|c|}{ Exogenous variables: $\mathrm{C}$} \\
\hline \multicolumn{6}{|c|}{ Sample: 140} \\
\hline \multicolumn{6}{|c|}{ Included observations: 38} \\
\hline Lag & $\log \mathrm{L}$ & LR & FPE & AIC & SIC \\
\hline 0 & -221.2131 & NA & 0.006291 & 11.95858 & 12.21715 \\
\hline 1 & -73.98442 & $240.2152 *$ & $1.85 \mathrm{e}-05^{*}$ & $6.104443^{*}$ & $7.914407 *$ \\
\hline 2 & -46.38359 & 36.31688 & $3.34 \mathrm{e}-05$ & 6.546505 & 9.907866 \\
\hline \multicolumn{6}{|c|}{ * indicates lag order selected by the criterion } \\
\hline \multicolumn{6}{|c|}{ L.R.: sequential modified L.R. test statistic (each test at $5 \%$ level) } \\
\hline \multicolumn{6}{|c|}{ FPE: Final prediction error } \\
\hline \multicolumn{4}{|c|}{ AIC: Akaike information criterion } & & \\
\hline
\end{tabular}

Publihsed by: 
SIC: Schwarz information criterion

H.Q.: Hanna-Quinn information criterion

\section{Unit root testing}

A unit root is a stochastic trend in time series analysis. They are sometimes called random walk. If time series data has a unit root, it shows a systematic pattern that is unpredictable. Unit roots are the test for stationary in time series data. Unit root test checks the predictable power of the time series data. The Augmented Dickey fuller test is commonly used for unit root testing. All the variables are non-stationary in their level form. The P-values of all variables are more than 0.05 , and the absolute value of the ADF test is less than the critical value of tstatistics in both intercept and trend and intercept form. So, we can reject the null hypothesis of saying they have a unit root. All variables are stationary in their first difference because Pvalues are less than 0.05 , and the absolute value of $\mathrm{ADF}$ is more than the absolute value of $\mathrm{t}$ statistics. The outcomes of the ADF test are listed in table 3.

Table 3

Results of Augmented Dickey-Fuller Test (ADF)

\begin{tabular}{lllllc}
\hline $\begin{array}{l}\text { Series } \\
\text { name }\end{array}$ & Description & Level & & First Difference \\
\hline \multirow{2}{*}{ LnNTR } & t- value & Intercept & $\begin{array}{l}\text { Trend \& } \\
\text { intercept }\end{array}$ & Intercept & $\begin{array}{l}\text { Trend \& } \\
\text { intercept }\end{array}$ \\
& ADF test & -2.938 & -3.529 & -2.943 & -3.536 \\
& P-value & 0.724 & 0.305 & -6.325 & -6.549 \\
LnDD & t-value & -2.938 & -3.529 & -2.941 & 0.000 \\
& ADF test & -0.408 & -2.162 & -7.116 & -3.533 \\
& P-value & 0.898 & 0.496 & 0.000 & -7.022 \\
LnCFFF & t- value & -2.938 & -3.529 & -2.941 & 0.000 \\
& ADF test & -2.476 & -2.864 & -5.736 & -3.533 \\
& P-value & 0.129 & 0.185 & 0.000 & -5.682 \\
LnPI & t value & -2.938 & -3.529 & -2.941 & -0.0002 \\
& ADF value & -2.092 & -2.068 & -7.979 & -8.533 \\
& P-value & 0.248 & 0.549 & 0.000 & 0.0003 \\
LnRFS & t- value & -2.941 & -3.529 & -2.941 & -3.533 \\
& ADF value & -0.243 & -2.165 & -15.944 & -15.749 \\
& P-value & 0.923 & 0.494 & 0.000 & 0.000 \\
LnRS & t- value & -2.943 & -3.536 & -2.943 & -3.536 \\
& ADF value & -0.112 & -2.286 & -9.569 & -9. \\
& P-value & 0.941 & 0.431 & 0.000 & 0.000 \\
\hline
\end{tabular}

Source: - Authors Calculation.

Where,

Publihsed by: 
Volume 1 No 1 November 2021

LnCFFF $=$ Charges, fees, fines, and forfeiture after taking the log

LnRFS = Receipt from sales after taking the log.

LnDD = Dividend after taking log

LnRS = Royalty and sales from fixed assets after taking the log

LnPI $=$ Principal and Interest Payment after taking the log

LnNTR $=$ Total Non-tax revenue after taking log

\section{Measurement of Impact on non-tax revenue of its Determinants}

Non-tax revenue is the revenue received by the government without tax revenue. Non-tax revenue is the sum of revenue received from charges, fees, fines and forfeiture, dividend, principal and interest payment, income from royalty betterment levy, and other sources without taxes. The income received from charges, fees, fines, and forfeiture (CFFF) is significant to explain the non-tax revenue. Similarly, principal and interest payment (P.I.), income received from the sale (RFS) are substantial to justify the dependent variable, i.e. non-tax revenue. More than $50 \%$ of independent variables are essential to explain the dependent variable. So, this model is robust and near reality. The value of R- the square is $99.39 \%$ which is more than $60 \%$. Therefore, independent variables are nicely fitted. The probability value of F- statistics is 0.000 , which is less than 0.05 or a $5 \%$ level of significance. It means independent variables have a combined effect to determine the size of non-tax revenue.

\section{Table 4}

Measurement of impact and relation

Dependent Variable: LnNTR

Method: Least Squares

Sample (adjusted): 19812010

Included observations: 30 after adjustments

\begin{tabular}{lllll}
\hline Variable & Coefficient & Std. Error & t-Statistic & Prob.* \\
\hline C & 1.250258 & 0.356505 & 3.506983 & 0.0019 \\
LnDD & 0.058082 & 0.089390 & 0.649767 & 0.5223 \\
LnCFFF & 0.127429 & 0.031963 & 3.986825 & 0.0006 \\
LnPI & 0.199006 & 0.042788 & 4.650947 & 0.0001 \\
LnRFS & 0.392211 & 0.185793 & 2.111012 & 0.0458 \\
LnRS & 0.041540 & 0.039562 & 1.049998 & 0.3046 \\
LnNTR(-1) & 0.192438 & 0.132797 & 1.449110 & 0.1608 \\
\hline R-squared & 0.993911 & Mean dependent variance & 8.333732 \\
Adjusted R-squared & 0.992322 & S.D. dependent variance & 1.278705 \\
S.E. of regression & 0.112042 & Akaike info criterion & -1.338917 \\
Sum squared residual & 0.288730 & Schwarz criterion & -1.011971 \\
Log-likelihood & 27.08376 & Hannan-Quinn criteria. & -1.234324 \\
F-statistic & 625.7063 & Durbin-Watson stat & 2.020304 \\
Prob (F-statistic) & 0.000000 & & \\
\hline Selin & &
\end{tabular}

Serial correlation P- value of observed R square $=0.4202$

Publihsed by: 
Heteroscedasticity (P-value of chi square) $=0.9424$

Jarque-Bera Normality ( $\mathrm{p}$ value $)=0.6638$

Source: - Authors calculation

Depending upon table 4, the regression line can be developed:

LnNTR $=1.250+0.058 \mathrm{LnDD}+0.127 \mathrm{LnCFFF}+0.199 \mathrm{LnPI}+0.392 \mathrm{LnFRS}+0.042 \mathrm{LnRS}$ $+0.192 \operatorname{LnNTR}(-1)$

According to Table 4, the Probability of the observed R square is more than 5\% that is $42.02 \%$. So, there is no problem with serial correlation. The value of heteroscedasticity is 0.9424 , which is more than 0.05 . It confirms the absence of residual heteroscedasticity. The result of the Jarque-Bera normality test indicates that residuals are not normally distributed. Different diagnostic ensures the reliability of this model.

\section{Forecasting of non-tax revenue}

The ordinary least square model has no serial correlation problem, no problem of heteroscedasticity, and residuals are not normally distributed. So, we can use this model in forecasting. The forecasting of the dependent variable, i.e. non-tax revenue from 2011 to 2019, is presented in figure 2 .

\section{Figure 2}

Forecasting of dependent variable

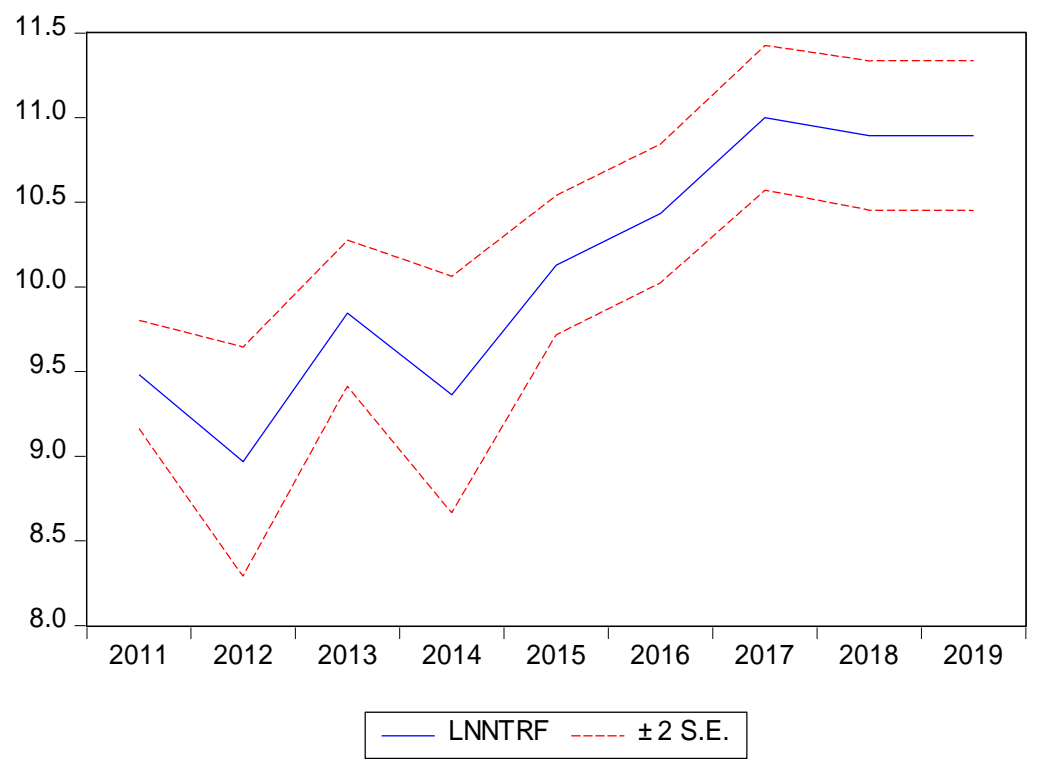

Forecast: LNNTRF

Actual: LNNTR

Forecast sample: 20112019

Included observations: 9

Root Mean Squared Error $\quad 0.786455$

Mean Absolute Error

0.659914

Mean Abs. Percent Error

6.197433

Theil Inequality Coefficient

0.037633

Bias Proportion

0.667433

Variance Proportion

0.151569

Covariance Proportion

0.180998

Theil U2 Coefficient

3.689688

Symmetric MAPE

6.488483

Figure 2: foresting of non-tax revenue

Figure 2 shows the ex-post forecasting of the dependent variable, i.e. non-tax revenue. The blue line is the forecasted value of non-tax revenue. The blue line is passing through the $95 \%$ confidence interval. So, our forecasting is good. It means it has good predicting or forecasting 
power. The value of root means squared error is 0.7865 , which is relatively small. Therefore, forecasted non-tax revenue (LNNTRF) and actual non-tax revenue (LNNTR) are moving closer. Recall that root mean squared error is taken as a benchmark to decide the capacity of predicting power. Root mean squared error is a gap between actual and forecasted value. The predicting power of our regression model is good and satisfactory.

The gap between forecasted non-tax revenue and actual non-tax revenue is presented in figure 3.

Figure 3

Difference between actual value and forecasted value.

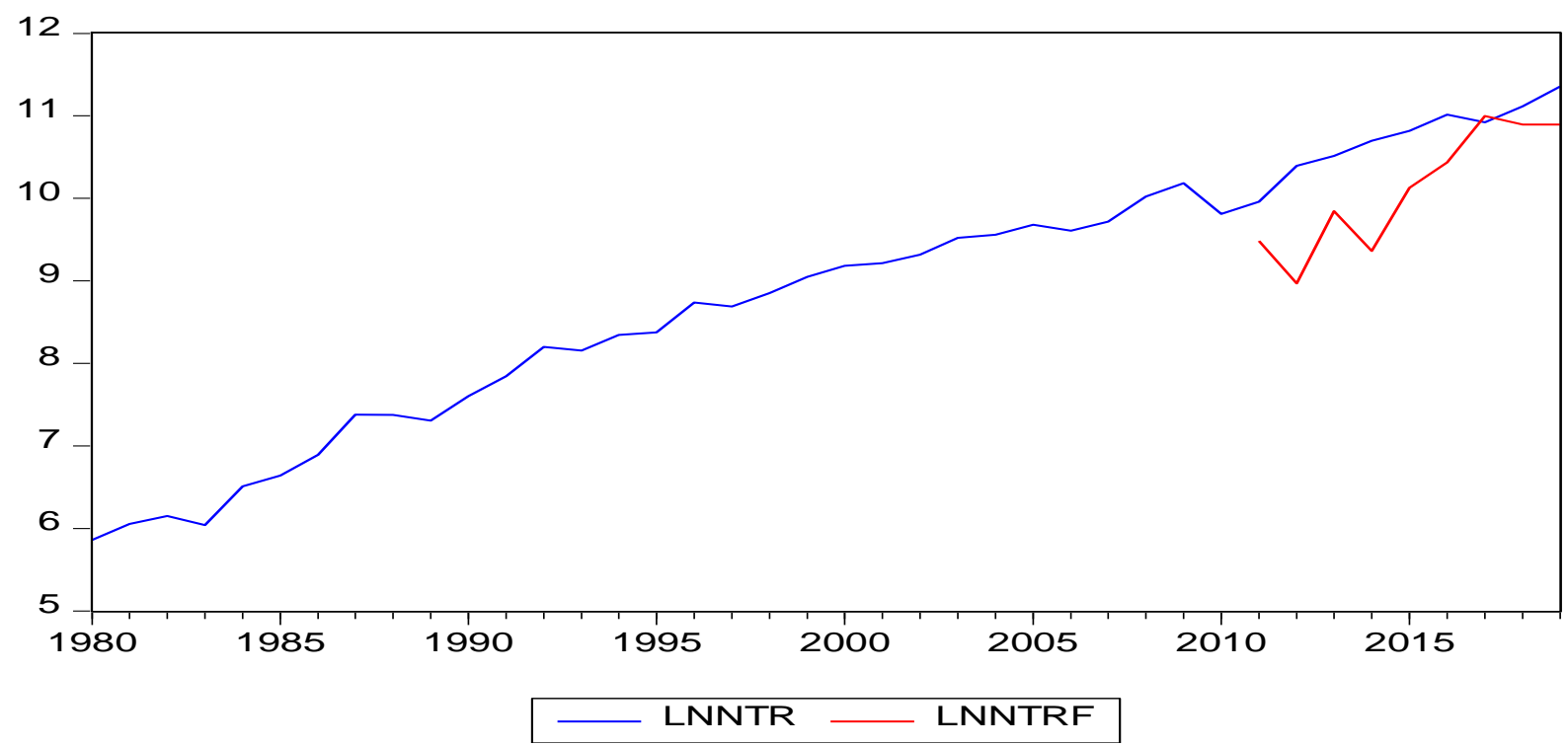

Figure: - 3 Comparison of forecasted and actual non-tax revenue.

Figure 3 shows the condition of the gap between forecasted and actual non-tax revenue. The blue line shows the accurate data, and the red line shows the estimated or projected non-tax revenue data. They are moving together. The Predicted value of non-tax revenue is closer to the actual data of non-tax revenue of Nepal.

\section{Conclusion}

The non-tax revenue depends upon income received from charges, fees, fines forfeiture, sales from government services, principal and interest payment, Royalty, and income from fixed assets, dividends, and so on. All determinants of non-tax revenue are increasing with some variation in some years. The average non-tax revenue is found 17090 million rupees during 40 years. The income received from principal and interest payment is found more consistent, but the income received from sales is found more variable than other non-tax revenue sources. All determinants of non-tax revenue have a positive impact on non-tax revenue. They have a combined effect of increasing the size of non-tax revenue in Nepal. The ex-post forecasting 
dynamic model shows that the forecasted and actual non-tax revenue moved together, and their gap is relatively small.

The ex-post forecasting model may be the guideline for the anti-post forecasting process. All determinants have a positive impact on increasing the size of non-tax revenue. So, sources of non-tax revenue must be supplemented, i.e. it is necessary to explore the new sources of nontax revenue, which may be the extension of particular sources of non-tax revenue. An increase in non-tax revenue may fulfil the heads of government revenue. An increase in non-non tax revenue may not increase the general public's dissatisfaction than the rise in the tax rate.

This study covers 40 years from 1980 (the fiscal year 1979/80) to 2019 (The fiscal year 2018/19). It is based on the secondary data collected from various economic surveys of Nepal. The ordinary least square and ex-post dynamic approach of forecasting are used. Many variables are, and the numbers of techniques are untouched. Therefore further research is needed by using other variables, tools, techniques, and data processing software. The untouched area of this topic is forwarded to other researchers.

\section{References}

Bagchi, A. (2005). Symposium on the report of twelfth finance commission: introduction and overview, Economic and Political Weekly, July 30 - August 5, Pg. 3388-3395.

Dahal, A. K., Dhakal, G., \& Thapa, K. K. (2020). Role of tax revenue, non-tax revenue, and foreign aid to increase the size of budget in Nepal. Asian Journal of Advanced Research and Reports, 14(4), 31-48. https://doi.org/10.9734/ajarr/2020/v14i430341

Ghimire, P., (2019). Role of tax towards government revenue of Nepal. International Journal of Business and Economics Research 8(3), pp. 85-96. DOI: 10.11648/j.ijber.20190803.12

GoN (2020). Economic Survey of Nepal F/Y 2019/20. Kathmandu, Government of Nepal, Ministry of finance.

GoN, (2001). Economic Survey of Nepal F/Y 2000/01. Kathmandu, Government of Nepal, Ministry of finance.

GoN, (2009). Economic Survey of Nepal F/Y 2008/09. Kathmandu, Government of Nepal, Ministry of finance.

Gujarati, D., N., (1995). Basic Econometrics. New York, McGraw. Hill, Inc.

Gupta, A.S (2007). Determinants of tax revenue effects in developing countries, International Monetary Fund, Working paper no. 07/184

Kaur, H. (1991). Taxation and development finance in India. Published Ph. D. thesis, Classical Publishing Co., New Delhi, 1991.

Kaur, H., and Gursimran (2010), Revenue of the central government of India: Pre and Post Reform Position. Journal of Engineering, Science and Management Education, 3(4); Pg. 2732.

Publihsed by: 
Kulshrestha, S., \& Sharma, R. (2015). An Analysis of Non-Tax Revenue Buoyancy in India. International Journal of Research in Economics and Social Sciences. 5(5), Email id: editorijrim@gmail.com, http://www.euroasiapub.org

Mawia, M. and J. Nzomoi. (2013). An Empirical Investigation of Tax Buoyancy in Kenya. African Journal of Business Management, 7 (40), pp. 4233-4246

Mohanty, A. (2014). Effectiveness in Management of Sub-national government Finance: An Empirical Analysis for Odisha. Odisha Review. Pp: 31-40.

Mohanty, A.S., and Patra, S.K., (2016). Impact on non-tax revenue on revenue expenditure in sub-national public finance in the economic sector. Journal of economics and finance, 5(1), pp 47-62 DOI: 10.9790/5933-0705014762 www.jesrjournals.org

Mourre, G, and Reut, A., (2017). Non-Tax Revenue in the European Union: A Source of Fiscal Risk? Luxembourg: Publications Office of the European Union, Discussion Paper 044 doi: $10.2765 / 63789$ (online)

Niyazmetov, I. (2018). Study on Causes of Taxation System's Inefficiency: Evidence from Uzbekistan. International Journal of Management Science and Business Administration, 4(3), pp. 61-72. DOI: 10.18775/ijmsba.1849-5664-5419.2014.43.1007

Poterba, J. (2011). Introduction: economic analysis of tax expenditures. National Tax Joyrnal, 64(2), 451-457. Retrieved May 2. 2021, from http://www.jstor.org/stable/41862579

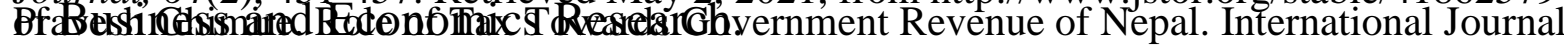

Prichard, W., Salard, P., and Segal, P., (2018). Taxation, non-tax revenue, and democracy: New evidence using new cross country data, World development Vol. 109; pp. 295-312, https://doi.org/10.1016/j.worlddev.2018.05.014

Purohit, M., \& Purohit, V. (2009). Mobilizing Non-Tax Revenue: An Empirical Analysis of Trends in States. Economic and Political Weekly, 44(5), 54-62. Retrieved April 20, 2021, from http://www.jstor.org/stable/40278460.

Upender, M (2008), Degree of Tax Buoyancy in India: An Empirical Study, International Journal of Applied Econometrics and Quantitative Studies, Vol. 5-2, pp. 60-70.

W.B. (2012). Creating fiscal space through revenue mobilization: An overview of economic developments in South Asian countries. Washington DC, The World Development Bank. www.Worldbank.org

\section{Copyrights}

Copyright for this article is retained by the author(s), with first publication rights granted to the journal.

This is an open-access article distributed under the terms and conditions of the Creative Commons Attribution license (http://creativecommons.org/licenses/by/4.0/) 